\title{
PENGEMBANGAN MODUL PRAKTIKUM KIMIA BAHAN ALAM: ISOLASI TRITERPENOID LUPEOL DARI DAUN MANGROVE Sonneratia alba
}

\author{
Nurlaila Ramdhaniah ${ }^{1 *}$, Aliefman Hakim ${ }^{2}$, Eka Junaidi ${ }^{3}$ \\ ${ }^{123}$ Program Studi Pendidikan Kimia, Universitas Mataram. Jalan Majapahit No. 62 \\ Mataram, NTB 83112, Indonesia. \\ * Coressponding Author. E-mail: lailramdhaniah@gmail.com
}

\begin{abstract}
Received: 26 Oktober 2020 Accepted: 13 Agustus $2021 \quad$ Published: 14 Agustus 2021
doi: 10.29303/cep.v4i2.2128
\end{abstract}

\begin{abstract}
Abstrak
Penelitian ini merupakan penelitian $R \& D$ (Research and Development) yang bertujuan untuk mengetahui: (1) langkah-langkah proses pengembangan modul praktikum kimia bahan alam tentang isolasi triterpenoid lupeol dari daun mangrove Sonneratia alba., (2) Tingkat kevalidan serta kepraktisan modul praktikum kimia bahan alam tentang isolasi triterpenoid dari daun mangrove Sonneratia alba yang dikembangkan. Model penelitian yang digunakan adalah model 4D (define, design, development, and dissemination). Teknik pengambilan sampel adalah random sampling dengan menggunakan rumus Slovin pada populasi mahasiswa program studi pendidikan kimia semester 8 yang berjumlah 67 mahasiswa dan sampel penelitian yang diperoleh yaitu 18 mahasiswa. Hasil penelitian menunjukkan nilai validitas dari dua orang validator yang diperoleh menggunakan indeks Aiken's adalah $\mathrm{V}=0,77$ dan nilai praktikalitas dari respon mahasiswa yang menunjukkan rata-rata praktikalitas semua komponen sebesar $84 \%$ dari respon sampel mahasiswa. Berdasarkan data tersebut dapat disimpulkan bahwa modul praktikum kimia bahan alam tentang isolasi triterpenoid lupeol dari daun mangrove Sonneratia alba termasuk dalam katergori valid dan sangat praktis untuk digunakan dalam proses pembelajaran mata kuliah Kimia Bahan Alam.
\end{abstract}

Kata kunci: pengembangan, modul, kimia bahan elam, Lupeol, Sonneratia alba.

\section{The Development of Natural Chemistry Laboratory Work Module: Triterpenoid Lupeol Isolation From the Leaves of Mangrove Sonneratia alba}

\begin{abstract}
This research is a Research and Development $(R \& D)$ which focused on discovering: (1) the steps in the process of developing a natural chemistry material lab module about the isolation of triterpenoid lupeol from the leaves of mangrove Sonneratia alba. (2) The level of validity and practicality of the practicum module developed. The research design used was the 4D model (define, design, development, and disseminate). The technique used was random sampling, using the Slovin formula which population in this study included all students of the $8^{\text {th }}$ semester of chemistry education study program amounting 67 students and the sample in this study obtained eighteen of them. The results showed that the validity of the two validators obtained using the Aiken's index was $V=0.77$ and the practicality of all practicum module components amounting to $84 \%$ of student responses. Based on these data, it can be concluded that the practicum module of the natural chemistry materials about the isolation of triterpenoid lupeol from the leaves of mangrove Sonneratia alba categorized in valid and practical so that it can be used in the learning process for natural chemistry's class.
\end{abstract}

Keywords: development, practicum module, natural chemistry, Lupeol, Sonneratia alba.

\section{PENDAHULUAN}

Pendidikan adalah proses pembelajaran yang dapat membantu seseorang dalam mengembangkan potensinya (Gustinasari,dkk.,
2017). Salah satu lembaga pendidikan yang memiliki peranan sangat besar dalam meningkatkan kualitas sumber daya manusia adalah perguruan tinggi (Nulhaqim,dkk., 2015). Pendidikan Kimia adalah salah satu program 


\section{Chemistry Education Practice, 4 (2), 2021 - 122}

Ramdhaniah, Hakim, Junaidi

studi yang ada diperguruan tinggi Universitas Mataram yang memiliki peranan dalam meningkatkan kualitas sumber daya manusia melalui kegiatan pembelajaran akademik dan keterampilan melalui proses perkuliahan tatap muka di kelas dan ditunjang dengan adanya kegiatan praktikum di laboratorium. Keterampilan mahasiswa dapat ditingkatkan melalui kegiatan praktikum pada pembelajaran kimia.

Salah satu mata kuliah yang wajib yang diprogramkan bagi mahasiswa program studi pendidikan kimia, Universitas Mataram adalah Kimia Bahan Alam. Mata kuliah Kimia Bahan Alam mempelajari tentang senyawa metabolit sekunder yang terdiri atas struktur, sifat dan asal usul biosintesis senyawa polifenol, terpenoid, steroid, flavonoid, alkaloid dan beberapa senyawa alam yang berguna serta melakukan isolasi metabolit sekunder dan mengkomunikasikan hasil isolasi senyawa metabolit sekunder referensi yang diperoleh (RPS Kimia Bahan Alam, 2018). Kegiatan pembelajaran mata kuliah Kimia Bahan terdiri dari 2 SKS untuk pertemuan di dalam kelas dan 1 SKS kegiatan praktikum. Praktikum sendiri merupakan bentuk pembelajaran yang dilakukan pada suatu tempat tertentu, dimana mahasiswa berperan aktif dalam menyelesaikan problem yang diberikan melalui penggunaan alat, bahan dan metode tertentu (Mahmudah,dkk., 2018).

Proses kegiatan praktikum yang dilakukan tentunya bertujuan untuk memberikan mahasiswa pengalaman secara langsung dalam isolasi senyawa kimia, sehingga dapat meningkatkan penguasaan konsep, kemampuan memecahkan masalah dan keterampilan ilmiah, memahami bagaimana sains dan ilmuwan bekerja, menumbuhkan minat dan motivasi serta melatih keterampilan berpikir. Proses isolasi senyawa kimia terutama metabolit sekunder membutuhkan adanya panduan dalam kegiatan mengisolasi senyawa metabolit sekunder. Salah satu bentuk panduan kegiatan praktikum yang biasa digunakan adalah modul (Pujani, 2014).

Kegiatan praktikum Kimia Bahan Alam yang biasa dilakukan yaitu memisahkan senyawa metabolit sekunder dari bahan-bahan alam. Senyawa metabolit sekunder berupa molekul-molekul kecil, bersifat spesifik artinya tidak semua organisme mengandung senyawa sejenis, mempunyai struktur yang bervariasi dan setiap senyawa memiliki fungsi/peran yang berbeda-beda (Atun, 2014). Senyawa metabolit sekunder dapat dipisahkan dari bahan-bahan alam melalui proses isolasi yang terdiri atas ekstraksi, fraksinasi, pemurnian dan identifikasi (Mahmudah,dkk., 2018). Isolasi adalah proses pemisahan suatu komponen kimia yang diinginkan dari komponen-komponen lainnya yang bersifat sebagai kontaminan dalam suatu bahan (Wasia,dkk., 2017). Isolasi bahan alam pada umumnya mengacu pada metabolit sekunder. Metabolit sekunder dihasilkan dari organisme, dimana merupakan suatu senyawa dengan berat molekul yang rendah dan dalam jumlah yang kecil. Peranan metabolit sekunder yaitu sebagai komponen pendukung, seperti yang digunakan untuk mempertahankan diri dari musuh dan hormone, serta bukan komponen utama seperti pertumbuhan dan reproduksi (Nugroho,dkk., 2017).

Salah satu jenis tumbuhan yang dapat dimanfaatkan adalah daun mangrove Sonneratia alba. Tumbuhan mangrove memiliki kemampuan khusus untuk beradaptasi dengan kondisi lingkungan yang ekstrim, seperti kondisi tanah yang tergenang, kadar garam yang tinggi, serta kondisi tanah yang kurang stabil (Rusila. 2006). Kemampuan untuk bertahan hidup dan tumbuh dalam lingkungan ekstrim tersebut disebabkan adanya perlindungan dari senyawa metabolit sekunder. Beberapa penelitian tentang potensi tumbuhan Sonneratia alba sebagai bahan alam dengan kandungan senyawa metabolit sekunder pada daun mangrove Sonneratia alba yaitu mengandung senyawa triterpenoid, fenol, steroid, saponin, dan tannin (Rahmania,dkk., 2018).

Triterpenoid adalah salah satu senyawa metabolit sekunder turunan terpenoid yang kerangka karbonnya berasal dari enam satuan isoprene dan secara biosintesis diturunkan dari hidrokarbon C30 asiklik. Triterpenoid berupa senyawa tidak berwarna, berbentuk kristal, dan biasanya bertitik leleh tinggi. Senyawa triterpenoid dapat dikelompokkan menjadi triterpenoid trisiklik, tetrasiklik, dan pentasiklik (Heliawati. 2018:18). Salah satu turunan triterpenoid pentasiklik adalah lupeol yang memiliki berat molekul $426 \mathrm{gr} / \mathrm{mol}$. Lupeol adalah triterpenoid yang aktif secara farmakologis dan berpotensi sebagai obat memiliki rumus kimia $\mathrm{C}_{30} \mathrm{H}_{50} \mathrm{O}$ (Wahyuono, 1993). Senyawa lupeol berbentuk serbuk putih, mempunyai titik lebur $202^{\circ} \mathrm{C}-204^{\circ} \mathrm{C}$, menurut 


\section{Chemistry Education Practice, 4 (2), 2021 - 123}

Ramdhaniah, Hakim, Junaidi

pustaka untuk bentuk amorph-nya mempunyai titik lebur $202,5^{\circ} \mathrm{C}$ (Riyanto, 2001).

Modul secara umum dapat diartikan sebagai satuan program pembelajaran terkecil yang dapat dipelajari mahasiswa secara perseorangan (self instructional), setelah menyelesaikan satu satuan dalam modul, selanjutnya mahasiswa dapat melangkah maju dan mempelajari satuan modul berikutnya ) (Nuralamsyah,dkk., 2017). Prastowo (2014) menyatakan bahwa modul memiliki beberapa keunggulan antara lain yaitu, a) berfokus pada kemampuan berpikir siswa, karena pada hakikatnya mereka memiliki kemampuan untuk bekerja sendiri dan harus lebih bertanggung jawab terhadap tindakannya; b) adanya control pada hasil belajar siswa melalui kompetensi dasar yang harus dicapai oleh siswa.

Berdasarkan hasil observasi, praktikum kimia bahan alam diterapkan dengan kegiatan praktikum berbasis proyek. Kegiatan praktikum berbasis proyek dilakukan dengan memberikan kesempatan bagi mahasiswa untuk menyelesaikan kegiatan praktikum secara sendiri, namun tetap dalam bimbingan dosen pengampu. Pembelajaran menggunakan modul adalah suatu pendekatan belajar mandiri yang terfokus pada penguasaan kompetensi sesuai dengan kondisi dan potensinya. Peran modul bagi mahasiswa sangat besar dalam mencapai tujuan pembelajaran baik pembelajaran mandiri maupun pembelajaran kelompok. Penggunaan media dan sumber belajar bagian dari komponen yang mempengaruhi pembelajaran. Kegiatan pembelajaran saat ini menekankan pada keterampilan proses dan active learning, maka media pembelajaran menjadi semakin penting (Tejo. 2011: 20) dalam Sutanto (2017: 1). Modul dapat memfasilitasi peserta didik dalam belajar mandiri maupun kovensional atau kelompok.

Berdasarkan penelitian yang dilakukan oleh Musa dkk (2017), lupeol berhasil diisolasi dari daun mangrove Sonneratia alba yang menghasilkan triterpenoid lupeol dengan berat $109 \mathrm{mg}$. Pada penelitian ini, metode isolasi dari Musa dkk (2017), dimodifikasi dan diharapkan tetap dapat menghasilkan kristal lupeol yang murni dengan rendemen yang tinggi dengan proses isolasi yang lebih mudah dan hasil isolasi yang lebih banyak. Sehingga dikembangkan modul praktikum yang berisi langkah isolasi lupeol yang lebih singkat dan penggunaan bahan menjadi lebih sedikit (lebih ekonomis). Oleh karena itu, dilakukan penelitian untuk referensi dan pengayaan isolasi bahan alam senyawa metabolit sekunder sebagai upaya meningkatkan kemampuan mahasiswa dalam isolasi senyawa tentang isolasi lupeol dari daun mangrove Sonneratia alba.

\section{METODE}

Penelitian ini dilaksanakan bulan JuniJuli 2020, pada mahasiswa semester 8 program studi Pendidikan Kimia, Universitas Mataram. Model yang digunakan pada penelitian ini adalah model 4D yang terdiri dari pendefinisian (define), perancangan (design), pengembangan (develop), dan penyebaran (disseminate). Namun, pengembangan yang dilaksanakan pada penelitian ini hanya dibatasi sampai pada tahap ketiga yaitu pengembangan (develop) dari model yang dicetuskan Thiagarajan (Haviz, 2013). Adapun yang dikembangkan dalam penelitian ini yaitu modul praktikum kimia bahan alam isolasi lupeol dari daun mangrove Sonneratia alba. Metode penelitian ini adalah survey dengan menggunakan instrument angket.

Populasi dalam penelitian ini adalah mahasiswa semester 8 Program Studi Pendidikan Kimia, Fakultas Keguruan dan Ilmu Pendidikan, Universitas Mataram angkatan 2016 yang terdiri dari tiga kelas dengan jumlah mahasiswa secara keseluruhan adalah 67 orang. Teknik pengambilan sampel adalah random sampling (Sugiyono. 2015) dengan menggunakan rumus Slovin dan sampel penelitian yang diperoleh sebanyak 18 orang mahasiswa.

Penelitian ini menggunakan dua jenis instrumen, yaitu lembar validasi ahli dan angket respon mahasiswa. Pengambilan data menggunakan instrumen berupa validitas ahli kepada dosen bertujuan untuk menentukan tingkat kevalidan modul praktikum, sedangkan pengambilan data untuk respon mahasiswa menggunakan instrumen berupa angket yang kemudian diserahkan kepada mahasiswa (sampel) untuk menetukan tingkat kepraktiksan modul praktikum. Teknik analisis data yang digunakan untuk lembar validasi modul dianalisis dengan statistik Aiken's V dan angket respon mahasiswa dianalisis menggunakan skala praktikalitas.

Tabel 1. Skala Praktikalitas

\begin{tabular}{lcc}
\hline No & Nilai & Kriteria \\
\hline 1. & $80 \%<\mathrm{x} \leq 100 \%$ & Sangat praktis \\
2. & $60 \%<\mathrm{x} \leq 80 \%$ & Praktis \\
\hline
\end{tabular}




\begin{tabular}{llc}
\hline 3. & $40 \%<\mathrm{x} \leq 60 \%$ & Cukup praktis \\
4. & $20 \%<\mathrm{x} \leq 40 \%$ & Kurang praktis \\
5. & $0 \%<\mathrm{x} \leq 20 \%$ & Tidak praktis \\
\hline
\end{tabular}

(Hidayati, 2017)

\section{HASIL DAN PEMBAHASAN}

Tahapan kegiatan pengembangan modul praktikum yang dilakukan diperoleh hasil sebagai berikut:

\section{Tahap Pendefinisian (Define)}

Pendefinisian (Define) merupakan tahap paling awal dalam penelitian. Pada tahap ini dilakukan analisis awal akhir dan analisis materi. Hasil analisis diperoleh dari studi literatur pada beberapa jurnal serta Rancangan Pembelajaran Semester (RPS) dan Rancangan Tugas Mahasiswa (RTM). Berdasarkan hasil analisis terhadap Rancangan Pembelajaran Semester (RPS) yang terdiri dari kemampuan akhir yang diharapkan, bahan kajian serta indikator capaian yaitu melalui serangkaian kuliah tatap muka, penugasan, diskusi, dan praktikum mahasiswa semester VI S-1 Pendidikan Kimia FKIP Universitas Mataram diharapkan mampu menganalisis struktur, sifat dan asal usul biosintesis senyawa polifenol, terpenoid, steroid, flavonoid, alkaloid \& beberapa senyawa alam yang berguna serta melakukan isolasi metabolit sekunder dan mengkomunikasikannya untuk menyadari keteraturan ciptaan Tuhan YME, maka modul praktikum yang dikembangkan digunakan dalam satu semester yaitu terdiri dari 3 (1) sks berisi 16 pertemuan dengan rincian 8 pertemuan materi teoritis (termasuk UTS dan UAS) yang dilakukan dengan pembelajaran tatap muka dikelas dan 8 pertemuan yang terbagi dalam 4 percobaan praktikum (preparasi sampel, maserasi, rekristalisasi dan identifikasi senyawa lupeol) digunakan untuk praktikum isolasi senyawa metabolit sekunder yaitu isolasi lupeol dari daun mengrove Sonneratia alba. Sehingga luaran tugas yang dihasilkan berupa tugas kelompok yang dibuat dalam bentuk proposal sederhana mengenai isolasi lupeol dari daun mengrove Sonneratia alba yang diimplementasikan di laboratorium serta membuat laporan praktikum tentang isolasi lupeol dari daun mengrove Sonneratia alba.

Analisis jurnal mengenai isolasi lupeol bertujuan untuk mengetahui proses isolasi lupeol dari daun mengrove Sonneratia alba, karakteristik senyawa dan pelarut yang digunakan serta tujuan praktikum yang akan dicapai. Berdasarkan analisis jurnal tersebut peneliti membuat rangkaian skema kerja isolasi lupeol dari daun mengrove Sonneratia alba yang terdiri dari skema kerja utama dan skema kerja modifikasi. Skema kerja modifikasi tersebut dijadikan sebagai acuan untuk melakasanakan praktikum isolasi lupeol dari daun mengrove Sonneratia alba.

Berdasarkan praktikum tentang isolasi lupeol dari daun mengrove Sonneratia alba yang telah dilakukan didapatkan kristal kafein berwarna putih berbentuk jarum dengan berat kristal sebesar $98 \mathrm{mg}$ dari 250 gram sampel daun mangrove Sonneratia alba dengan rendemen sebesar $0,04 \%$. Kristal lupeol yang didapatkan kemudian dimurnikan menggunakan Kromatografi Lapis Tipis (KLT) yang dan disemprotkan $\mathrm{H}_{2} \mathrm{SO}_{4} 2 \mathrm{~N}$ sehingga terlihat spot berwarna ungu berjumlah satu spot. Kristal lupeol kemudian dianalisis dengan spektroskopi IR dan spektroskopi UV-Vis. Berdasarkan hasil analisis spektroskopi IR didapatkan spektrum lupeol dengan kemiripan $\pm 95 \%$ dengan spektrum yang ada pada literatur. Gugus-gugus fungsi yang teridentifikasi pada spektrum IR hasil isolasi sesuai dengan gugus fungsi yang ada pada struktur lupeol pada literature acuan. Gugus fungsi O-H ditunjukkan pada $3436 \mathrm{~cm}^{-1}$, gugus $\mathrm{C}=\mathrm{C}$ ditunjukkan pada $1639 \mathrm{~cm}^{-1}$, gugus $\mathrm{C}-\mathrm{H}$ alifatik ditunjukkan pada kisaran 2850-2919 $\mathrm{cm}^{-1}$.Berikut gambar spektrum IR lupeol hasil isolasi:

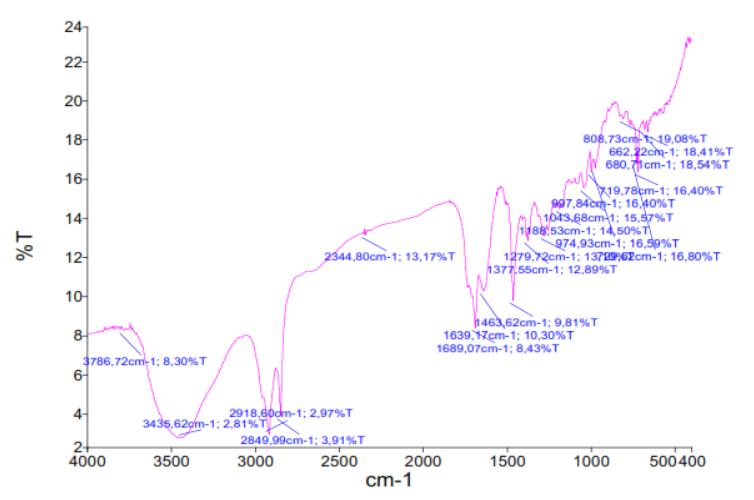

Gambar 1. Spektrum FT-IR Lupeol Hasil Isolasi

Pada analisis spektroskopi UV-Vis didapatkan puncak (peak) tertinggi pada panjang gelombang 216,40nm. Hal ini menunjukkan bahwa struktur senyawa lupeol isolasi tidak memiliki ikatan rangkap terkonjugasi, dimana puncak (peak) ikatan rangkap terkonjugasi berada pada panjang 
gelombang diatas $250 \mathrm{~nm}$. Berikut gambar spektrum UV-Vis lupeol hasil isolasi:

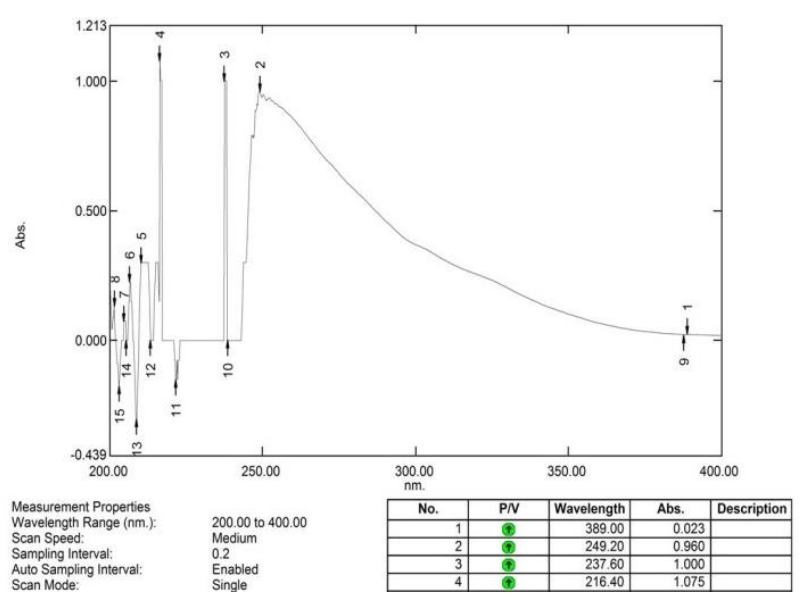

Gambar 2. Spektrum UV-Vis Lupeol Hasil Isolasi

Berdasarkan hasil praktikum tersebut, dapat disimpulkan bahwa serbuk yang didapatkan oleh peneliti pada praktikum adalah senyawa lupeol, sehingga metode skema kerja modifikasi yang digunakan dapat dijadikan sebagai acuan untuk proses pembuatan modul praktikum kimia bahan alam tentang isolasi lupeol yang dikembangkan.

Berdasarkan hasil analisis diatas, maka pada tahap pendefinisian ini ditentukan batasan permasalah dan materi yang akan dikembangkan didalam modul praktikum yang terbagi menjadi dua yaitu materi teoritis dan prosedural. Materi-materi ini dipaparkan dari beberapa buku kimia bahan alam dan jurnal mengenai isolasi senyawa metabolit sekunder. Adapun materi teoritis terdiri dari pengertian dan tujuan isolasi, peralatan dan bahan-bahan isolasi senyawa metabolit sekunder, ekstraksi senyawa metabolit sekunder yang terdiri dari pengertian ekstraksi, polaritas pelarut dan pemilihan pelarut, faktor-faktor yang mempengaruhi ekstraksi serta penentuan struktur senyawa metabolit sekunder. Selain itu, diberikan pemaparan mengenai karakteristik tanaman mangrove Sonneratia alba serta senyawa lupeol yang akan diisolasi dari daun mangrove Sonneratia alba. Adapun materi prosedural, diberikan pemaparan mengenai proses maserasi, kristalisasi, rekristalisasi, dan pemurnian senyawa hasil rekristalisasi menggunakan Kromatografi Lapis Tipis dan analisis spektroskopi IR dan UV-Vis.

\section{Tahap Perancangan (Design)}

Tahap perancangan merupakan langkah selanjutnya yang dilakukan berdasarkan beberapa hasil identifikasi pada tahap pendefinisian atau analisis. Pada tahap ini dilakukan penyusunan modul yang diawali dengan perancangan cover, penyusunan komponen modul (1) yaitu kata pengantar, daftar isi, tata tertib praktikum dan pengenalan laboratorium kimia, (2) proses praktikum, berisi tentang judul praktikum, tujuan praktikum, materi terkait dengan praktikum, prosedur kerja berupa percobaan-percobaan praktikum, hasil pengamatan, pengolahan data, pertanyaan dan pembahasan praktikum. Setelah melakukan perancangan terhadap modul praktikum, didapatkan hasil dari tahap perancangan atau design yaitu berupa modul praktikum prototype 1.

\section{Tahap Pengembangan (Development)}

Perangkat pembelajaran yang dikembangkan dapat dikatakan berkualitas apabila memenuhi kriteria sebagai berikut yaitu (1) validitas (validity) dan kepraktisan (praticality). Penelitian ini bertujuan untuk menghasilkan produk berupa modul praktikum yang valid dan praktis untuk digunakan dalam proses pembelajaran. Pada tahap ini produk awal (prototype 1) yang dihasilkan diuji kevalidannya dengan uji validitas untuk mendapatkan masukan serta saran yang membangun agar modul praktikum yang dikembangkan lebih baik dan layak digunakan sebagai media praktikum. Uji validitas tersebut menggunakan instrumen berupa lembar validasi ahli yang berisi komponen kegrafikan, komponen penyajian, komponen kelayakan isi dan komponen kebahasaan. Instrumen penelitian tentunya berkenaan dengan validitas dan reliabilitas ${ }^{[13]}$.

Analisis yang digunakan dalam menentukan tingkat kevalidan modul yaitu indeks Aiken dimana validitas di lakukan pada dua orang validator. Kevalidan (validitas) modul yang dikembangkan dapat dilihat pada gambar 3 . 


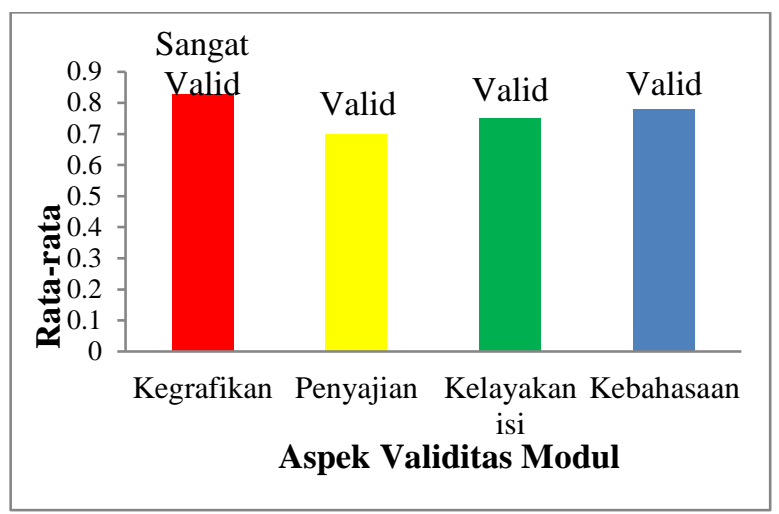

Gambar 3. Kevalidan Modul

Hasil validasi dari dua validator memberikan nilai valid $(\mathrm{V}=0,77)$ terhadap modul praktikum dan dapat digunakan setelah melakukan revisi sesuai dengan saran-saran yang sudah diberikan (Mustaming dan Nurlaela, 2015). Setelah melakukan validasi terhadap modul praktikum maka didapatkan hasil dari tahap pengembangan yaitu modul praktikum prototype 2 . Selanjutnya prototype 2 diuji cobakan kepada mahasiswa semester 8 program studi Pendidikan Kimia tahun akademik 2019/2020, Fakultas Keguruan dan Ilmu Pendidikan, Universitas Mataram.

Uji kepraktisan yang dilakukan yaitu pada 18 orang mahasiswa program studi Pendidikan Kimia, Universitas Mataram. Pada tahap ini, uji kepraktisan dilaksanakan untuk memperoleh respon mahasiswa terhadap modul praktikum yang dikembangkan. Angket respon mahasiswa yang digunakan terdiri dari 21 butir pernyataan dimana 10 pernyataan untuk komponen kemenarikan modul, 7 pernyataan untuk komponen kemudahan penggunaan modul, 2 pernyataan untuk komponen waktu pelaksanaan modul dan 2 pernyataan untuk komponen manfaat modul. Hasil analisis angket respon mahasiswa diperoleh rata-rata mahasiswa menunjukkan respon baik terhadap modul praktikum yang telah dikembangkan. Praktikalitas semua komponen modul diperoleh nilai rata-rata respon mahasiswa sebesar $84 \%$ yang menunjukkan modul praktikum yang dikembangkan berada pada kategori sangat praktis (Zakirman dan Hidayati, 2017). Berikut grafik hasil respon mahasiswa terhadap modul yang dikembangkan:

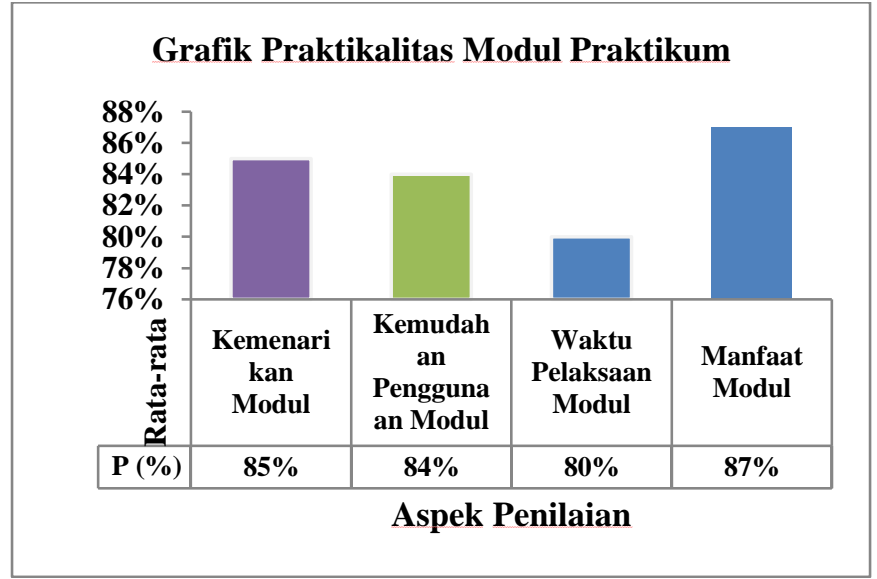

Gambar 4. Kepraktisan Modul

Setelah dilakukan validasi dan uji kepraktisan terhadap modul praktikum yang dikembangkan, maka didapatkan hasil dari tahap pengembangan yang disebut dengan modul praktikum prototype 3. Berdasarkan hasil validasi serta angket respon mahasiswa, maka diperoleh kesimpulan bahwa modul praktikum kimia bahan alam tentang isolasi lupeol dari daun mangrove Sonneratia alba telah valid dan praktis digunakan dalam proses pembelajaran.

\section{Tahap Penyebaran (Dissemination)}

Pada tahap ini, yang dilakukan adalah penyebaran produk dalam hal ini modul praktikum yang dikembangkan, dengan melakukan sosialisasi kepada dosen dan mahasiswa terhadap modul yang telah divalidasi oleh para validator (ahli) dan telah diuji kepraktisan pada responden. Sosialisasi modul ini dimaksudkan untuk memperkenalkan modul yang telah dikembangkan dan telah memenuhi syarat sehingga dapat digunakan sehingga dapat digunakan pada proses pembelajaran. Akan tetapi, karena adanya keterbatasan waktu dan kondisi selama pandemik, maka proses penyebaran atau dissemination ini tidak dilaksanakan, sehingga penelitian ini hanya dilakukan sampai tahap pengembangan (development) yaitu pada tahap uji kevalidan dan kepraktisan.

\section{SIMPULAN}

Berdasarkan data hasil penelitian dan pembahasan, dapat disimpulkan bahwa pengembangan modul praktikum kimia bahan alam tentang isolasi lupeol dari daun mangrove Sonneratia alba yang dikembangkan menggunkan model 4D telah terlaksana dan diperoleh modul praktikum kimia bahan alam 
isolasi lupeol dari daun mangrove Sonneratia alba yang bersifat valid dan sangat praktis digunakan dalam proses pembelajaran mata kuliah Kimia Bahan Alam.

\section{SARAN}

Proses pengembangan modul praktikum isolasi senyawa lupeol dari daun mangrove Sonneratia alba dengan model 4D yang dilakukan oleh peneliti hanya sampai tahap pengembangan (development) yaitu uji kepraktisan. Sehingga diharapkan penelitian selanjutnya dapat dilakukan sampai tahap penyebaran (dissemination) dan uji coba terbatas dengan melakukan sosialisasi terhadap modul praktikum yang dikembangkan kepada dosen dan mahasiswa dan uji kriteria keefektifan.

Selain itu untuk analisis lebih lanjut, dapat pula ditambahkan dengan jenis spektroskopi lainnya, seperti H-NMR dan C-NMR. Sehingga diharapkan mahasiswa mendapatkan pengetahuan dan pengalaman yang lebih luas tentang analisis spektroskopi.

\section{DAFTAR PUSTAKA}

Atun, S, 2014. Metode Isolasi dan Identifikasi Struktur Senyawa Organik Kimia Bahan Alam. Jurnal Konservasi Cagar Budaya Borobudur, Vol. 8, No. 2 hal: 53-61.

Gustinasari, M.L. dan Ardi., (2017). Pengembangan Modul Pembelajaran Berbasis Konsep Disertai Contoh pada Materi Sel untuk Siswa SMA. Bioeducation Journal, Vol. 1, No. 1 hal: 60-73.

Haviz. M. 2013. Research and Developments ; Penelitian Di Bidang Pendidikan yang Inovatif, Produktif, dan Bermakna. Jurnal Ilmiah Ta'dib. Vol.16. No. 1: 28-43.

Heliawati, L. 2018. Kimia Organic Bahan Alam. Bogor: Pascasarjana UNPAK.

Mahmudah, S. Sukib, S. dan Hakim, A., 2018. Pengembangan Modul Praktikum Kimia Bahan Alam: Isolasi Trimiristin dari Pala. Chemistry Education Practice, Vol. 1, No. 1 hal: 20- 25.

Musa, W.J.A., Duengo S., \& Tahir.R. H. 2017. Senyawa Triterpenoid dari Tumbuhan Mangrove (Sonneratia alba). Jurnal ITEKIMA. Vol.1.No.1: 36-44.
Mustaming, C. A. M. dan Nurlaela L. 2015. Pengembangan Perangkat Pembelajaran Memperbaiki Unit Kopling dan Komponen-Komponen Sistem Pengoperasiannya dengan Model Discovery Learning untuk Meningkatkan Hasil Belajar Siswa Kelas XI Otomotif SMK Negeri 2 Tarakan. Jurnal Pendidikan Vokasi: Teori dan Praktek. Vol.3, No.1: 81-95.

Nugroho, E.B.P., Budiasih E, dan Sukarianingsih D. 2017. Pengembangan Buku Petunjuk Praktikum Kimia SMA/MA Kelas X Semester 2 Berbasis Learning Cycle. Jurnal Inovasi Terknologi Pendidikan. Vol.4. No.1:817-813.

Nulhaqim, S.A H., R. R. Pancasilawan, R. dan Fedriyansyah, M., 2015. Peranan Perguruan Tinggi dalam Meningkatkan Kualitas Pendidikan di Indonesia untuk Menghadapi ASEA Comunity 2015. Social Work Jurnal,Vol. 6, No. 2 hal: 154-272.

Nuralamsyah R. 2017. Pembuatan Modul Berbasis Komputer Pada Mata Kuliah Praktek Dasar Dan Pengukuran Listrikteknik Elektronika Universitas Nger Makassar. Jurnal ILTEK. Vol.12.No.1: 1706-1712.

Prastowo, A. 2014. Panduan Kreatif Membuat Bahan Ajar Inovatif. Yogyakarta : Diva Press.

Pujani, Ni Made., (2014). Pengembangan Perangkat Praktikum Ilmu Pengetahuan Bumi dan Antariksa Berbasis Kemampuan Generik Sains untuk Meningkatkan Keterampilan Laboratorium Calon Guru Fisika. Jurnal Pendidikan Indonesia,Vol. 3, No. 2 hal: 471-484.

Rahmania, N., Rozirwan H. 2018. Phytochemical Test of Mangrove Avicennia alba, Rhyzophora apiculata and Sonneratia alba from Musi River Estuary, South Sumatera. BIOVALENTIA: Biological Research Journal. Vol. 4. No.2, hal: 8-15.

Retnawati, Heri. 2016. Analisis Kuantitatif Instrumen Penelitian. Yogyakarta: Parama Publishing.

Riyanto, Sugeng., Sukari.M.. A. 2001. Identifikasi Dan Uji Bioaktivitas Lupeol dan Marmin yang Dipisahkan 
Chemistry Education Practice, 4 (2), 2021 - 128

Ramdhaniah, Hakim, Junaidi

dari Korteks Aegle marmelos. Jurnal

Biologi. Vol.2. No.11:685-692.

Rusila, N. Y., Khazali M., Suryadiputra I. N.

N. 2006. Panduan Pengenalan

Mangrove di Indonesia. Bogor:

PHKA/WI-IP.

Sugiyono., (2015). Metode Penelitian

Pendidikan Pendekatan Kuantitatif,

Kualitatif dan $R \& D$. Penerbit

Alfabeta. Bandung.

Sutanto, P., 2017 Panduan Praktis

Penyusunan e-Modul. Jakarta:

Direktur Pembinaan SMA, Depdiknas.

Wahyuono, S. 1993. Identifikasi Lupeol dan

Lupeil $\beta$-Hidroksioktadekanoat Yang

Terdapat Didalam Fraksi Non-Polar

Amsonia Grandiflora (Fam.

Apocynaceae). Majalah Farmasi

Indonesia. Vol. 4. No.4: 180-189.

Wasia, N. H. Sudarma, I. M. Savalas, L. R. T. dan Hakim, A., 2017. Isolasi Senyawa Sinamaldehid dari Batang Kayu Manis (Cinnamomum Burmanii) dengan Metode Kromatografi Kolom. Jurnal Pijar MIPA, Vol. 12, No. 2 hal: 91-94.

Zakirman dan Hidayati. 2017. "Praktikalitas Media Video dan Animasi dalam Pembelajaran Fisika Di SMP”. Jurnal Ilmiah Pendidikan Fisika Al-BiRuNi. 6 (1): 85-93. 